\title{
PEMBUATAN MEDIA PEMBELAJARAN INTERAKTIF CIRI - CIRI MAHLUK HIDUP DAN LINGKUNGAN HIDUPNYA DI KELAS III SD NEGERI 01 SELUMA
}

\author{
Ilmiati $^{1}$, Pitri Ilian Kusmadi ${ }^{2}$ \\ ${ }^{1}$ Sekolah Dasar Negeri 01, ${ }^{2}$ Sekolah Dasar Negeri 126 \\ Jalan Bengkulu Tais, Desa Air Periukan Kabupaten Seluma \\ Ilmiati@gmail.com, Pitriiliankusmadi@gmail.com
}

\begin{abstract}
So far, the delivery of teaching and learning activities still uses conventional methods or face to face (lectures). With this method effective and efficient goals are not achieved so that it requires interactive multimedia-based learning media. Computer as one of the ICT products is considered appropriate to be used as a tool in learning, various kinds of learning approaches are packaged in the form of computer-based learning programs or Computer Assisted Instruction (CAI). With the development of ICT in this learning, so that the expository method is felt to be inadequate. The purpose of this study is to produce learning media characteristic of living things for third grade students of SD Negeri 01 Seluma. The benefits of this learning media is to be a solution to the learning process that is effective, interesting and more fun and facilitates student learning.

Keywords: Learning Media, Interactive
\end{abstract}

Abstrak - Selama ini dalam penyampaiana kegiatan belajar mengajar masih menggunakan metode konvensional atau tatap muka (ceramah). Dengan metode tersebut tidak tercapai tujuan yang efektid dan efisien sehingga dibutuhkan media pembelajaran berbasis multimedia interaktif. Komputer sebagai salah satu produk TIK dinilai tepat digunakan sebagai alat bantu dalam pembelajaran, berbagai macam pendekatan pembelajaran yang dikemas dalam bentuk program pembelajaran berbentuk komputer atau Computer Assisted Instruction (CAI). Dengan berkembangnya TIK dalam pembelajaran ini, sehingga dengan metode ekspositori dirasakan belum memadai.Tujuan penelitian ini adalah untuk menghasilkan media pembelajaran ciri- ciri mahluk hidup untuk siswa kelas III SD Negeri 01 Seluma. Manfaat media pembelajaran ini adalah menjadi solusi proses pembelajaran yang efektif, menarik dan lebih menyenangkan serta memudahkan proses belajar siswa.

Kata Kunci : Media Pembelajaran, Interaktif

\section{PENDAHULUAN}

\section{A. Latar Belakang}

Pendidikan sebagai salah satu bagian tidak terpisahkan dari proses pendewasaan manusia tentu di satu sisi memiliki peranan yang besar bagi pengembangan ilmu pengetahuan dan teknologi tersebut. Namun, di sisi lain pendidikan juga perlu memanfaatkan kemajuan ilmu pengetahuan dan teknologi agar mampu mencapai tujuan secara efektif dan efisien. Kualitas pendidikan dapat dipengaruhi oleh kurikulum, proses pembelajaran, metode pengajaran, evaluasi, buku ajar, mutu guru, saran dan prasarana pendidikan. Dalam dunia pendidikan, pemanfaatan perangkat Teknologi Informasi dan Komunikasi (TIK) sangat membantu proses belajar mengajar. Seperti yang disebutkan dalam laporan hasil penelitian yang dikeluarkan oleh Computer Technology Research bahwa seseorang hanya akan mendapat $20 \%$ dari apa yang mereka lihat dan $30 \%$ dari yang mereka dengar. Sedangkan melalui multimedia akan mendapat $50 \%$ dari apa yang mereka lihat dan dengar sampai $80 \%$ dari apa yang mereka lihat, dengar dan berinteraksi dengan pada waktu yang sama (1).

Sejak berlakunya Kurikulum Tingkat Satuan Pendidikan (KTSP) untuk Sekolah Dasar (SD) terdapat struktur kurikulum Keterampilan Komputer (Mulok sekolah). Tetapi dalam penyampaian Kegiatan Belajar Mengajar (KBM) Ilmu Pengetahuan Alam (IPA) guru masih menggunakan metode konvensional atau tatap muka (ceramah), sehingga proses belajar mengajar menjadi tidak efektif, tidak menarik dan kurang menyenangkan (2).

Sekolah Negeri 01 Seluma, selama ini guru masih menggunakan metode konvensional atau tatap muka (ceramaah) dengan adanya media pembelajaran interaktif maka proses belajar mengajar lebih efektif dan efisien serta menarik dan menyenangkan bagi siswa. 


\section{B. Landasan Teori}

1. Pengertian Pembelajaran

Pembelajaran merupakan proses yang diselenggarakan oleh guru untuk membelanjakan siswa dalam belajar, bagaimana memperoleh, memproses pengetahuan, keterampilan serta sikap (3). Pembelajaran adalah proses interaksi peserta didik dengan pendidik dan sumber belajar pada suatu lingkungan belajar (4).

2. Pengertian Teknologi Informasi dan Komunikasi Teknologi Informasi dan Komunikasi (TIK), adalah payung besar terminologi yang mencakup seluruh peralatan teknis untuk memproses dan menyampaikan informasi. TIK mencakup dua aspek yaitu teknologi informasi dan teknologi komunikasi. Teknologi informasi meliputi segala hal yang berkaitan dengan proses, penggunaan sebagai alat bantu, manipulasi, dan pengelolaan informasi. Sedangkan teknologi komunikasi adalah segala sesuatu yang berkaitan dengan penggunaan alat bantu untuk memproses dan mentransfer data dari perangkat yang satu ke lainnya. Oleh karena itu, teknologi informasi dan teknologi komunikasi adalah dua buah konsep yang tidak terpisahkan. Jadi Teknologi Informasi dan Komunikasi mengandung pengertian luas yaitu segala kegiatan yang terkait dengan pemrosesan, manipulasi, pengelolaan, pemindahan informasi antar media. Istilah TIK muncul setelah adanya perpaduan antara teknologi komputer (baik perangkat keras maupun perangkat lunak) dengan teknologi komunikasi pada pertengahan abad ke-20. Perpaduan kedua teknologi tersebut berkembang pesat melampaui bidang teknologi lainnya (3).

\section{Pengertian Multimedia}

Multimedia adalah gabungan dari teks, suara, citra, maupun video. Dari gabungan media tersebut diintegrasikan ke dalam komputer untuk disimpan kemudian diolah dan disajikan secara bersamaan. Multimedia bermaksud memaksimalkan setiap indera dalam menerima suatu informasi (5).Secara umum, Multimedia interaktif merupakan kombinasi berbagai media dari komputer, video, audio, gambar dan teks. Berdasarkan definisi Hofstetter (2001) "multimedia interaktif adalah pemanfaatan komputer untuk menggabungkan teks, grafik, audio, gambar bergerak ( video dan animasi ) menjadi satu kesatuan dengan link dan tool yang tepat sehingga memungkinkan pemakai multimedia dapat melakukan navigasi, berinteraksi, berkreasi, dan berkomunikasi (6).

\section{Adobe Photoshop}

Adobe Photoshop adalah sebuah perangkat lunak Editor citra yang dugunakan untuk pengeditan foto atau gambar serta pemberian efek pada gambar tersebut. Pada pengembangan aplikasi ini Adobe Photoshop digunakan untuk merancang tampilan interface dari aplikasi (7).

\section{Adobe Flash CS 5.5}

Adobe Flash Pro CS5.5 merupakan salah satu softwere animasi yang sangat populer dan sudah di akui kecangihannya. Kelengkapan fasilitas dan kemampuan yang luar biasa dalam membuat animasi, menjadikan softwere ini banKelengkapan fasilitas dan kemampuan yang luar biasa dalam membuat animasi, menjadikan softwere ini banyak di pakai oleh animator Flash, karena keberadaannya benar-benar mampu membantu dan memudahkan pemakai dalam menyelesaikan pekerjaan, terutama pekerjaan animasi dan persentasi (3).

\section{HASIL DAN PEMBAHASAN}

\section{Analisi}

a. Identifikasi Masalah (Identify). Dalam dunia pendidikan suatu metode pembelajara dapat di hadirkan dengan menggunakan alat peraga pembelajaran atau sering di kenal dengan media pembelajaran.

b. Memahami Masalah (Understand). Salah satu metode pembelajaran yang sekarang ini dapat dikembangkan dengan mamanfaatkan teknologi computer.

c. Analisis Masalah (Analyze). Pembelajaran dengan computer akan dapat membantu memahami, karena computer akan menghadirkan bentuk pembelajaran yang menarik dan dengan computer dapat disajikan media pembelajaran yang memuat materi pembelajaran secara tekstual, audio maupun visual.

d. Analisis kebutuhan meliputi dua hal yaitu: Hardware (Perangkat Keras) dan Software (Perangkat Lunak). Adapun alat bantu tersebut sebagai berikut:

Perangkat keras (Hardware)

a. Intel Core i3

b. RAM 4GB

c. Harddisk 1 TB

d. VGA Card $1 \mathrm{~TB}$

e. Monitor SVGA dengan display setting $1024 \mathrm{x}$ 768 32-bit color 
f. Sound Card Realtek AC97 Audio

g. Speaker AKtif +Microphone

Perangkat Lunak (Software)

a. Sistem Operasi Windows 7

b. Adobe Photoshop

c. Adobe Flash CS5.5

2. Hasil Perancangan Interface Aplikasi

Berikut ditampilkan beberapa bagian hasil perancangan halaman Interface Aplikasi.

Pada saat aplikasi dibuka maka akan muncul halaman menu utama seperti pada gambar dibawah ini:

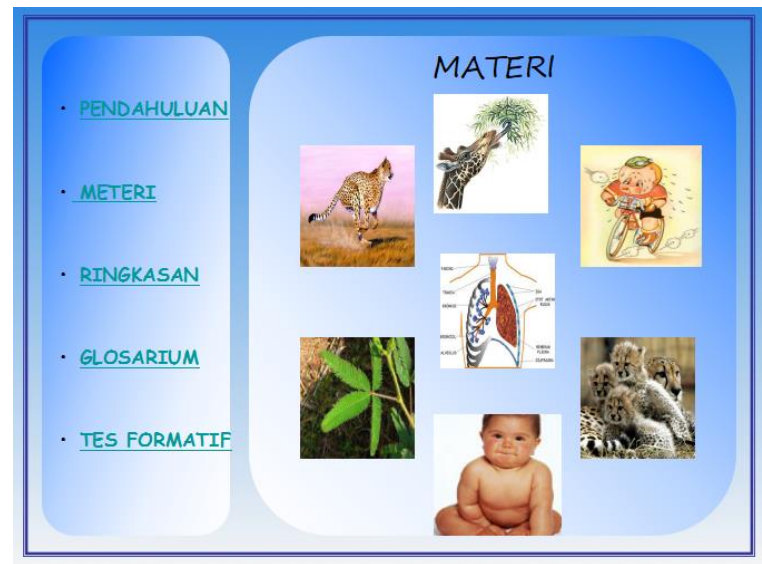

Di dalam menu materi terdapat menu bergerak pada hewan.

\section{BERGERAK}

Manusia dan hewan bergerak secara aktif, artinya disertai dengan perpindahan

Hewan memiliki alat gerak beranekaragam, antara lain:

- Kaki pada sebagian besar vertebrata

- Sirip pada ikan

- Sayap pada burung

- Kaki semu (psudopodia) pada Amoeba proteus

- Bulu cambuk (flagel) pada Euglena viridis

- Bulu getar (cilia) pada Paramecium caudatum
Pada Menu Ringkasan menu yang berisi tentang ringkasan materi

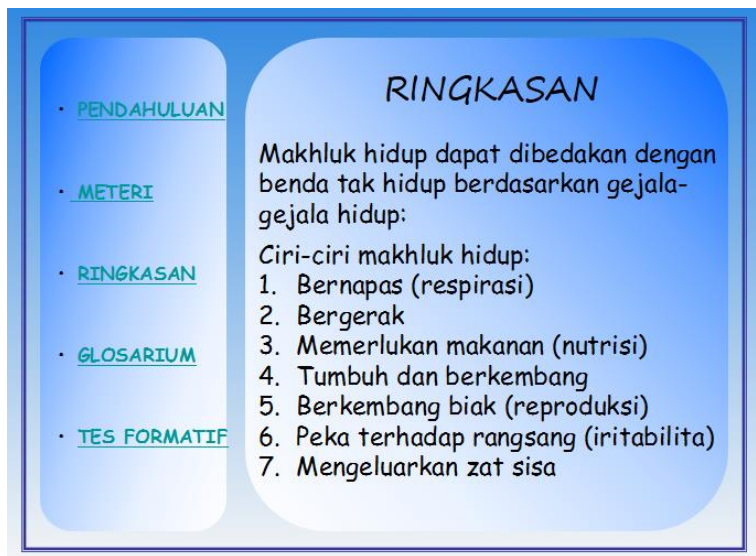

Menu Glosarium, menu yang berisi tentang gen, indra, embrio dll.

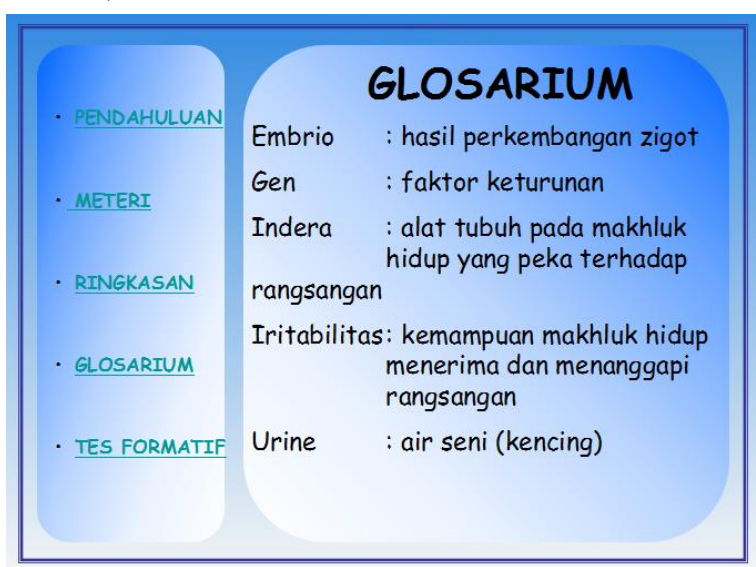

Menu Tes Formatif, menu ini berisi tentang kuis pengetahuan anak dalam memahami materi

125 | http://www.jurnal.umb.ac.id/index.php/JSAI 


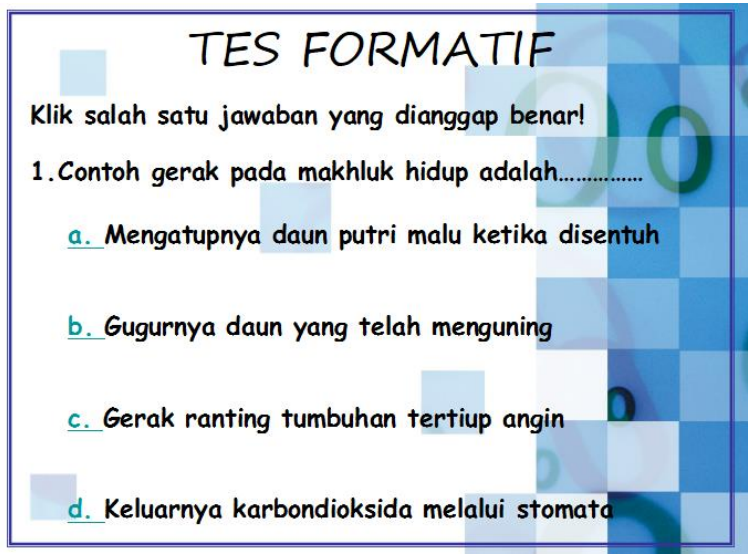

\section{KESIMPULAN DAN SARAN}

\section{A. Kesimpulan}

Media Pembelajaran interaktif ini dapat membantu pengajar dalam memberikan materi pembelajaran menjadi lebih efektif dan efisien. Sedangkan bagi siswa dengan adanya media ini membantu siswa dalam pemahaman materi lebih cepat dan menarik.

\section{B. Saran}

Pada pengembangan aplikasi ini penulis menyadari masih terdapat banyak kekurangan. Maka dari itu penulis mengharapkan saran serta kritik yang bersifat membangun untuk menjadi pembelajaran bagi penulis kedepannya.

\section{Referensi}

1. Penerapan Model Technology Acceptance Model (TAM) untuk Pemahaman Media Pembelajaran Berbasis Multimedia Interaktif. Syafrizal, Agusdi. s.1. : Scientific Journal of Informatics, 2015.

2. Pembuatan Media Pembelajaran Interaktif Ilmu Pengetahuan Alam Pada Sekolah Dasar Negeri Kroyo 1 Sragen. Neni Yuniati, Bambang Eka Purnama, Gesang Kristianto Nugroho. s.1. : Sentra Penelitian Engineering dan Edukasi, 2011.

3. PEMBUATAN MEDIA PEMBELAJARAN AKSARA JAWA PADA SEKOLAH DASAR NEGERI 2 GUNAN WONOGIRI KELAS VI . Trisno Haryoko, Bambang Eka Purnama. s.l. : Teknologi Informasi dan Komunikasi, 2013.

4. MEDIA PEMBELAJARAN INTERAKTIF MATEMATIKA UNTUK SISWA SEKOLAH DASAR KELAS IV. Wibowo, Endro Joko. s.l. :
Seminar Riset Unggulan Nasional Informatika dan Komputer FTI UNSA, 2013.

5. Chandra. Multimedia PC. Jakarta : P.T. Elex Media Komputido, 1999.

6. PERANCANGAN GAME PEMBELAJARAN ANAK USIA DINI MENGGUNAKAN HTML 5 BERBASIS MULTIMEDIA INTERAKTIF. Agusdi Syafrizal, Rio Andika, Ade Permadi Panggabean. Yogyakarta : Seminar Nasional Teknologi Informasi dan Multimedia, 2018.

7. Aplikasi Pengenalan Tempat Wisata Propinsi Bengkulu Menggunakan Teknologi Augmented Reality (Video Playback) Berbasis Android. Agusdi Syafriza, Muhammad Husni Rifqo, Miri Ardiansyah. s.l. : JTIS, 2018. 